\title{
Management of Canadian prairie region grazed grasslands: Soil C sequestration, livestock productivity and profitability
}

\author{
D. H. Lynch ${ }^{1}$, R. D. H. Cohen², A. Fredeen ${ }^{1}$, G. Patterson ${ }^{3}$, and R. C. Martin ${ }^{1}$ \\ ${ }^{1}$ Department of Plant and Animal Sciences, Nova Scotia Agricultural College, P.O. Box 550, Truro, Nova Scotia, \\ Canada B2N 5E3; ' 2 Department of Animal and Poultry Science, University of Saskatchewan, Agriculture Bldg., \\ 51 Campus Drive, Saskatoon, Saskatchewan, Canada S7N 5A8; ${ }^{3}$ Agriculture and Agri-Food Canada, Crop and \\ Livestock Research Centre (Charlottetown), Engineering Building, 20 Tower Rd., P.O. Box 550, NSAC, Truro, \\ Nova Scotia, Canada B2N 5E3. Received 2 August 2004, accepted 6 January 2005.
}

\begin{abstract}
Lynch, D. H., Cohen, R. D. H., Fredeen, A., Patterson, G. and Martin, R. C. 2005. Management of Canadian prairie region grazed grasslands: Soil C sequestration, livestock productivity and profitability. Can. J. Soil Sci. 85: 183-192. The GrassGro model (a computer simulation of management-induced changes in range and pasture forage and livestock productivity) was combined with spreadsheet analyses to estimate the influence of improved grazing practices on soil organic carbon (SOC), and farm profitability, across native rangelands and tame pastures of the southern Canadian Prairies. Improved practices included complementary grazing (CG) and reduced stocking density (RSD) on rangeland; and N fertilization (FERT), seeded grass/legumes grazed continuously (GLGC) or rotationally (GLGR), and RSD on tame pastures. The analysis was stratified into three ecoregions on the basis of similarities in climate and soil type. Averaged over $30 \mathrm{yr}$ and ecoregions, SOC rates of gain through improved management were 5 (RSD) to 26 (CG) $\mathrm{kg} \mathrm{C} \mathrm{ha}^{-1} \mathrm{yr}^{-1}$ for rangelands, and 86 (RSD), 75 (GLGC), 62 (GLGR) and 222 (FERT) kg C ha ${ }^{-1}$ $\mathrm{yr}^{-1}$ for tame pastures. Gains with FERT were considered largely negated by associated energy (C) costs, $\mathrm{N}_{2} \mathrm{O}$ emissions, and shifts in grassland species. The CG system alone improved net returns to the producer. The estimated potential combined SOC gain on prairie grazinglands (11.5 Mha) was $1.63 \mathrm{MMT} \mathrm{CO}_{2} \mathrm{yr}^{-1}$ (or $0.465 \mathrm{MMT} \mathrm{C} \mathrm{yr}^{-1}$ ), slightly less than the $1.70 \mathrm{MMT} \mathrm{CO}_{2}$ $\mathrm{yr}^{-1}$ currently emitted from agricultural soils in Canada.
\end{abstract}

Key words: Soil carbon, GrassGro model, grazing management, rangeland, tame pasture

\begin{abstract}
Lynch, D. H., Cohen, R. D. H., Fredeedn, A., Patterson, G. et Martin, R. C. 2005. Gestion des pacages dans la région des Prairies canadiennes : séquestration du C du sol, productivité du bétail et rentabilité. Can. J. Soil Sci. 85: 183-192. Les auteurs ont combiné le modèle GrassGro (simulation électronique des incidences des pratiques agricoles sur les fourrages des grands parcours et des pâturages et sur le rendement du bétail) aux analyses par chiffrier pour estimer les répercussions de meilleures pratiques de paissance sur le carbone organique du sol (COS) et sur la rentabilité des exploitations agricoles sur les grands parcours naturels et les prairies artificielles du sud des Prairies canadiennes. Parmi les pratiques améliorées, on retrouve la paissance complémentaire (PC) et la réduction de la densité de peuplement (RDP) pour les grands parcours ou, pour les prairies artificielles, les amendements azotés (ENG), la paissance continue (PCLG) ou en rotation (PRLG) de mélanges de légumineuses/graminées et la RDP. L'analyse a été stratifiée en trois écorégions d'après les similitudes au niveau du climat et du type de sol. Lorsqu'on calcule la moyenne de trente ans et celle des écorégions, on obtient un taux de croissance du COS de 5 (RDP) à 26 (PC) kg de C par hectare et par année pour les grands parcours et de 86 (RDP), 75 (PCLG), 62 (PRLG) et 222 (ENG) kg de C par hectare et par année pour les prairies artificielles. Les gains réalisés avec les amendements azotés sont dans une large mesure annulés par les coûts connexes de l'énergie, les dégagements de $\mathrm{N}_{2} \mathrm{O}$ et la modification des espèces dans les prairies. La PC améliore à elle seule les recettes nettes de l'éleveur. On estime le gain combiné potentiel de COS dans les pacages des Prairies (11,4 Mha) à 1,63 MMT de $\mathrm{CO}_{2}$ par année (0,465 MMT C par année), soit légèrement moins que les 1,70 MMT $\mathrm{CO}_{2}$ par année libérées par les sols agricoles du Canada.
\end{abstract}

Mots clés: Carbone du sol, modèle GrassGro, gestion de la paissance, grands parcours, prairies artificielles

Agricultural soils, if properly managed, have the potential to act as a net sink for $\mathrm{CO}_{2}$, and contribute significantly to a mitigation of greenhouse gas emissions and a reduction of atmospheric $\mathrm{CO}_{2}$ levels. Historic losses of SOC from cropland in Canada are on the order of $1 \mathrm{Pg}$ out of a total $4.3 \mathrm{Pg}$ $\mathrm{SOC}$, due in large part to cultivation of annual crops. Over
$80 \%$ of all arable land in Canada is found within the prairie region, and following cultivation of these predominately grassland soils, annual SOC losses initially exceeded 1.0 Mg C ha ${ }^{-1} \mathrm{yr}^{-1}$ (Bruce et al. 1999; Smith et al. 2000). Annual net $\mathrm{C}$ losses from Canadian agricultural soils are considered to have diminished greatly, however, and are

Abbreviations: ANPP, aboveground net primary productivity; Cc, cow-calf; CG, complementary grazing; CWG, crested wheatgrass; DMI, average daily total dry matter intake; DMD, digestibility (\%) of the dry matter consumed; FERT, N fertilization; GLGC, seeded grass/legumes grazed continuously; GLGR, seeded grass/legumes grazed rotationally; MAT, mean annual air temperature; MAP, mean annual precipitation; PPT/PEP, ratios of precipitation to potential evapotranspiration; RSD, reduced stocking density; SD, stocking density; SOC, soil organic carbon 
approaching zero (Smith et al. 1997; VandenBygaart et al. 2003).

The effects of management of cultivated land on the dynamics of SOC have been studied with increasing intensity in recent years. Studies from western US and Canada have assessed the $\mathrm{C}$ sequestration potential of such agricultural practices as the adoption of conservation tillage, reduction in fallow use, fertilization, increasing forages in rotation (Janzen et al.1998a, b; Campbell et al. 2000, 2001; Smith et al. 2001; VandenBygaart et al. 2003) and conversion of degraded or arable land to permanent grass cover (Barker et al. 1996; Bruce et al. 1999; Smith et al. 2001). However, limited published information exists on the potential for SOC sequestration through improved management of grazed grasslands of Canada. Soils maintained under grasslands store very large amounts of SOC and globally, grasslands account for $25 \%$ of all land surface stored C (Schimel 1995). By some estimates, the global rates of $\mathrm{C}$ gain through improved management of grazingland $\left(0.237 \mathrm{Gt} \mathrm{C} \mathrm{yr}^{-1}\right)$ would be approximately double the rate of $\mathrm{C}$ gain obtained through improved management of all cropland $\left(0.125 \mathrm{Gt} \mathrm{C} \mathrm{yr}^{-1}\right)$ by the year 2010 [Intergovernmental Panel on Climate Change (IPCC) 2001]. In summarizing a series of recent comprehensive reviews on the potential of US grazingland to sequester soil C, Follett et al. (2001) estimated that the 212 Mha of privately owned grazinglands in the United States could gain from 30 to 110 MMT C yr-1 (equivalent to $50 \%$ of the potential SOC gains assigned to US cropland) and meet $12 \%$ of the former US commitment under the Kyoto Protocol. While $45 \%$ of these C gains were derived from land conversion to, or restoration of perennial grasslands, $48 \%$ of these gains were due to the adoption of improved grazing management practices on current range and pasture land. Such a large potential for $\mathrm{C}$ storage from grazinglands is attributed to the extremely large area comprising grazingland, the comparatively low current intensity of management, and in arid and semiarid regions, the potential for grazinglands to sequester soil inorganic $\mathrm{C}$ (Follett et al. 2001).

Various management strategies such as modifying grazing regimes, irrigation, fertilization, improved species selection and introduction of legumes can be used to increase plant primary productivity and carbon fixation from grazed grassland (Bruce et al. 1999; Conant et al. 2001, 2002). The aboveground net primary productivity (ANPP) of the grasslands of North America is strongly influenced by the amount and distribution of annual precipitation (Sala et al. 1988). Where available moisture is less limiting, changes in nutrient supply can have major influences on grassland primary productivity, plant species composition, litter quality, $\mathrm{N}$ availability and SOC sequestration (Wedin and Tilman 1996; Burke et al. 1998; Schuman et al. 1999; Franzlubbers et al. 2000; Schnabel et al. 2001; Weinhold et al. 2001). In intensively managed pastures of the humid regions of North America, Franzlubbers et al. (2000) concluded that appropriate grazing strategies can produce $\mathrm{C}$ gains up to $1000 \mathrm{~kg}$ $\mathrm{C} \mathrm{ha}{ }^{-1} \mathrm{yr}^{-1}$. In arid and semi-arid regions, however, potential rates of $\mathrm{C}$ gain through improved management of nonintensively managed rangelands are suggested (Follett et al. 2001 ) to be in the $100-150 \mathrm{~kg} \mathrm{C} \mathrm{ha}^{-1} \mathrm{yr}^{-1}$ range. In Canada, perennial grasslands comprise approximately one-third of Canada's total agricultural landbase of 60.1 Mha (Statistics Canada 1996). Among the relatively small number of grazing studies that have attempted to quantify grazing management impacts on SOC, with a few exceptions (Weinhold et al. 2001), it is rare to find an integrated assessment of associated impacts on livestock production and farm profitability. The objectives of this study were to model and evaluate various improved grazing management options for the Prairie eco-regions of Canada with respect to impact on forage productivity and soil $\mathrm{C}$ gain, livestock performance and farm profitability.

\section{MATERIALS AND METHODS}

\section{Modeling Forage Yields, Livestock Productivity and Profitability of Grazing Management Options}

The total area under grass in the southern Canadian Prairies including tame pasture (formerly improved pasture) and rangeland (formerly unimproved pasture) were grouped at the eco-region level on the basis of similarities in climate and soil type using data provided by Statistics Canada (1996) and Agriculture and Agri-Food Canada (AAFC 1995) (Table 1; Fig. 1). The baseline grazing management scenarios and improved practices modelled for rangeland and tame pasture within each region are outlined in Table 2. Native rangelands containing a mixture of western wheatgrass (Pascopyrum smithii), northern wheatgrass (Agropyron dasystachyum), blue gramma grass (Bouteloua gracilis) and green needle grass (Stipa viridula) were modelled at several stocking densities and season lengths. Tame pastures of crested wheatgrass (CWG) (Agrpyron cristatum) with and without alfalfa (Medicago sativa) were compared at various levels of fertility inputs, stocking density and season length. As the overriding constraint of water limitation diminishes with increasing annual precipitation, herbivory and soil nitrogen, in addition to fire and light, gain in importance in determining grassland plant community and ecosystem dynamics (Burke et al. 1998). The drier prairie regions (Moist Mixed and Mixed Grassland) were considered too dry to experience benefits from $\mathrm{N}$ fertilization (FERT), seeded pastures of grass/legume grazed continuously (GLGC) or rotationally (GLGR), or complementary grazing $(\mathrm{CG})$ practices. These management strategies were therefore modelled for tame pastures and native rangelands in the moist prairie regions only.

Annual ANPP and associated soil C inputs (from combined phytomass residue and manure) were calculated using results obtained for each grazing management scenario tested using the GrassGro model (Cohen et al. 1995, 2003). GrassGro is a computer decision support system that predicts range, pasture, forage and ruminant livestock productivity under different management conditions in various locations of the Canadian Prairies. A daily time-step pasture growth model is driven by weather data (temperature, precipitation, evaporation and radiation) and predicts pasture growth and composition (populations of perennial or annual grasses or herbs, including legume). Biomass from each species is divided into live, standing dead and litter material before being assigned digestibility classes. Changes in 
Table 1. Summary of climate and soil characteristics for each prairie ecoregion and the coefficient for estimating soil $\mathrm{C}$ gains from crop residue inputs of $\mathbf{C}$

\begin{tabular}{|c|c|c|c|c|c|c|}
\hline \multirow[b]{2}{*}{$\begin{array}{l}\text { Prairie } \\
\text { ecoregions }^{\mathbf{z}}\end{array}$} & \multirow[b]{2}{*}{$\begin{array}{c}\text { Total area } \\
\text { grazed (Mha) } \mathbf{y}\end{array}$} & \multicolumn{3}{|c|}{ Climate $^{\mathbf{x}}$} & \multirow[b]{2}{*}{ Common soil typesw } & \multirow{2}{*}{$\begin{array}{c}\text { Efficiency of } \\
\text { conversion of } \\
\text { input C to } \\
\text { soil C }(\%)\end{array}$} \\
\hline & & $\begin{array}{l}\text { Mean summer } \\
\text { temperature }\left({ }^{\circ} \mathrm{C}\right)\end{array}$ & $\begin{array}{l}\text { Mean winter } \\
\text { temperature } \\
\left({ }^{\circ} \mathrm{C}\right)\end{array}$ & $\begin{array}{l}\text { Mean annual } \\
\text { precipitation } \\
\text { range }(\mathrm{mm})\end{array}$ & & \\
\hline $\begin{array}{l}\text { Aspen Parkland/ } \\
\text { Boreal Transition }\end{array}$ & 7.629 & 15 & -12.5 & $400-575$ & $\begin{array}{l}\text { Dark Gray and Black } \\
\text { Chernozems, Solonetzs }\end{array}$ & $20^{\mathbf{u}}$ \\
\hline Moist Mixed Grassland & 2.646 & 15.5 & -11 & $340-400$ & Dark Brown Chernozems, Solonetz & 15 \\
\hline Mixed Grassland & 4.993 & 16 & -10 & $250-350$ & Brown Chernozems, Solonetz & 5 \\
\hline
\end{tabular}

${ }^{\mathbf{z}}$ Adapted from AAFC (1995) A National Ecological framework for Canada.

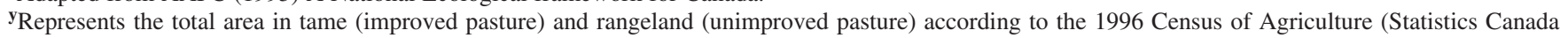
1996).

${ }^{\mathbf{x}}$ Approximations from climate data reported in AAFC (1995) A national ecological framework for Canada.

wAs described in AAFC (1995) A national ecological framework for Canada, and Tarnocai (1998).

uAs reported by Campbell et al. (2002).

digestibility are governed by temperature and moisture. An animal biology model is also included, which predicts ruminant consumption and assimilation of herbage and the production of liveweight, milk, wool and conceptus. The model was used to determine the effects of grazing management practices at two sites in Saskatchewan over a 30-yr time period from 1960 to 1989 . The two sites, Melfort [mean annual air temperature $(\mathrm{MAT})=0.3^{\circ} \mathrm{C}$, mean annual precipitation $(\mathrm{MAP})=411 \mathrm{~mm}$, evapotranspiration $(\mathrm{ET})=506$ $\mathrm{mm}]$, and Swift Current $\left(\mathrm{MAT}=3.3^{\circ} \mathrm{C}, \mathrm{MAP}=334 \mathrm{~mm}\right.$, $\mathrm{ET}=729 \mathrm{~mm}$ ), were taken as representative of responses within the moist prairie regions (Aspen Parkland/Boreal Transition) and dry prairie regions (Mixed Grassland, Moist Mixed Grassland), respectively. Complementary grazing is a management option currently promoted in the Prairie regions of Canada as one of the few grazing management systems that can substantially increase livestock production (Cohen et al. 1995). By successively moving grazing cattle to forage of different grasses that mature at different times of the season, the approach promotes more efficient use of herbage, improved condition of the range, and higher stocking rates (Gillen and Berg 2001). In the CG scenario examined for native rangelands, (Table 2) CWG was grazed from May 16 to Jul. 01, native range was grazed from Jul. 01 to Aug. 19, and Russian wild ryegrass (Psathyrostachys juncea) was grazed for the remainder of the season (Aug. 20 to Oct. 31).

GrassGro also provides data useful for economic evaluation of the different pasture management scenarios being tested, including the numbers of steers and heifers sold each season and their weaning weights. Data on the tonnes of feed supplement (usually hay) necessary under the different management schemes are also provided. All scenarios were for cow-calf (Cc) enterprises. The model ranch is 300 ha in size and numbers of mature and immature cattle on the ranch vary depending on stocking densities (SD), which are expressed as either breeding females or $\mathrm{Cc} \mathrm{ha}^{-1}$. A SD of 0.5 $\mathrm{Cc} \mathrm{ha}{ }^{-1}$ will have an average of 116 mature cows, 17 first calf heifers, and 17 bred heifers on the pasture each year. In reality, SD is never static, varying from year to year depend- ing on climatic factors, herbage production, the animals' body condition, and mortality and conception rates. Beef prices in western Canada for the fall $1998\left(\$ 2.10 \mathrm{~kg}^{-1}\right.$ for Hereford steers, $\$ 1.99 \mathrm{~kg}^{-1}$ for Hereford heifers) were used to estimate the profitability of each practice. Profits for each system were based on the value of the steers and heifers sold, minus the supplementary feed costs associated with each system. We assumed that a mature cow eats $9 \mathrm{~kg}$ of hay per day and that the winter feeding period is $197 \mathrm{~d}$.

\section{Estimates of Soil Organic Carbon Sequestration}

Gains in soil SOC content occur during transition from one SOC steady state to another, whereupon the rate of $\mathrm{C}$ input and decomposition again re-converge. The diversity in SOC response to modified management practices also reflects, however, the interaction with factors such as initial SOC status, climate and soil type (Janzen et al. 1998a). For example, the aridity common to the southern Canadian prairies acts as a severe constraint on primary productivity and soil $\mathrm{C}$ inputs. In addition, on long-term ( $>50 \mathrm{yr}$ ), well-managed (i.e., appropriate stocking rate) native rangelands the potential for SOC gain is likely minimal, as most of these native rangeland soils are being maintained at equilibrium SOC levels close to pre-settlement conditions (Bruce et al. 1999). Sufficiently heavy grazing, however, can promote a process of successive degradation of the rangeland resource in which decreased vegetative cover and productivity, soil runoff and erosion, and shifts in plant community composition lead to reduced herbage quality and decreased manurial returns and SOC inputs. The perpetuation of this degradation of the soil resource reduces forage production and livestock performance (Weinhold et al. 2001).

Most of the world's grasslands are overused (Bari et al. 1993; Conant et al. 2001) and more than half of Prairie rangeland is in less than good condition [Prairie Farm Rehabilitation Administration (PFRA) 2000]. Less productive and less palatable vegetative species dominate, and livestock carrying capacity is reduced. Traditional season-long (continuous) grazing regimes on the Canadian Prairies and heavier grazing intensities also increase soil compaction and 


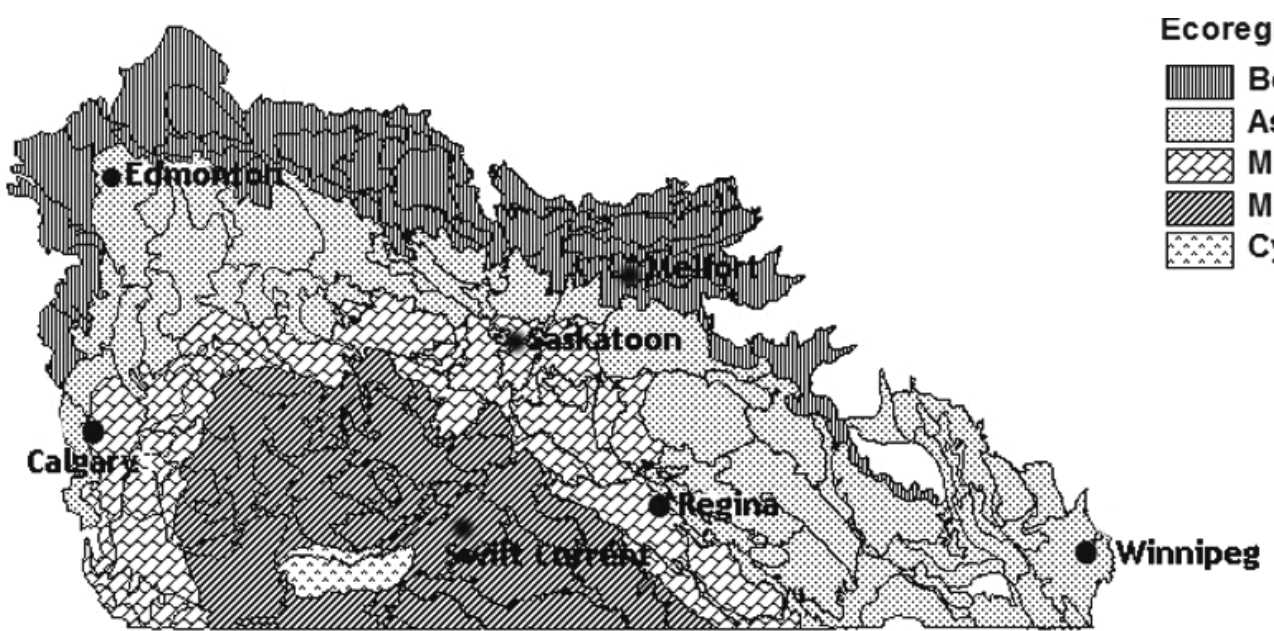

Ecoregion

Boreal Transistion

Aspen Parkland

Moist Mixed Grassland

Mixed Grassland

Cyprus Uplands

Fig. 1. Ecoregions of the southern Canadian prairies.

reduce litter carryover for moisture conservation (Chanaysk and Naeth 1995; Naeth et al. 1991). There is a lack of suitable information, stratified by grassland system (i.e., soil, climate and management combination) to accurately gauge historical losses of SOC stocks from Prairie grazed grasslands. IPCC revised good practices guidelines (Naburrs et al. 2004), however, assume $5 \%$ of SOC has been lost from overgrazed or moderately degraded temperate or boreal grasslands with reduced productivity. Conant et al. (2001), following a review of 115 grazing management studies conducted globally, found improved management increased SOC by an average of $7 \%$ for those study sites $(64 \%)$ with a long evolutionary history of grazing. Relatively heavy stocking rates are common on much of the Prairie rangelands (PFRA 2000). Consequently, we used heavily grazed $\left(0.4 \mathrm{Cc} \mathrm{ha}^{-1}\right.$ and 0.5 $\left.\mathrm{Cc} \mathrm{ha}^{-1}\right)$, full-season ranges as our baseline, business as usual, scenario when contrasting with improved practices for the modelled hectarage of native rangelands and tame pastures, respectively (Table 2). Further potential for SOC gain within the Prairie Region will be provided by those soils of relatively high productivity and low initial SOC contents, such as the smaller grazed areas of the Prairies (Boreal Plains, Montane Cordillera, Peace River Lowland) not included in this study, dominated by relatively low-SOC-content Luvisols and Brunisols, which developed under forest (Smith et al. 1997; Tarnocai 1998).

Rates of SOC accumulation per hectare for the first three decades after implementation of a practice were based on the difference between $\mathrm{C}$ inputs under the improved practice and the baseline scenario. There is generally a direct relationship between residue $\mathrm{C}$ inputs and SOC change (Campbell et al. 2002) and we assumed $C$ inputs were linked to aboveground production. Conant et al. (2001) concluded SOC gains with improved management were linked to increased grassland productivity in the majority of global studies reviewed. In contrast, Henderson et al. (2004) found Prairie rangeland class and aboveground productivity at nine locations in Alberta were not consistently linked to greater SOC. Sixty to ninety percent of the net primary productivity in grasslands occurs belowground and standing biomass pools can be rela- tively small in these systems compared to $\mathrm{C}$ stored in root biomass (Reeder et al. 2001; Schuman et al. 1999). The ratio of BNP:ANP (belowground net production:aboveground net production) varies from over 8:1 in warm-arid grassland regions to about 1.2:1 on most moist prairie sites (Burke et al. 1998; Reeder et al. 2001). Root residue C inputs were calculated using derived BNP:ANP ratios (Table 3). The IPCC default expansion factor to estimate BNP from ANP, ranges from 2.8 to 4.0 for semi-arid to Prairie grassland regions (Naburrs et al. 2004). We assumed a 25\% higher BNP:ANP ratio under grazing. There is some evidence that grazing enhances the BNP:ANP ratio (Sims and Singh 1978) although the deficiencies of current methodologies in providing accurate estimates of BNP, and wide variability of grazing study design, have made a definitive statement difficult (Milchunas and Lauenroth 1993). Annual plant residue inputs were determined by subtracting the cow and calf annual dry matter intake from the combined phytomass produced (ANP plus BNP):

$$
\begin{aligned}
& \text { Plant residue input }\left(\mathrm{kg} \mathrm{ha}^{-1} \mathrm{yr}^{-1}\right) \\
& =\mathrm{ANP}+\mathrm{BNP}-[((\text { cow DMI }- \text { cow supplement }) \\
& \quad+\text { calf DMI }) \times \text { grazing days }]
\end{aligned}
$$

Annual manure inputs were determined as:

$$
\begin{aligned}
& \text { Manure inputs }\left(\mathrm{kg} \mathrm{ha}^{-1} \mathrm{yr}^{-1}\right) \\
& =[((\text { Cow DMI }- \text { cow supplement }) \\
& \quad \times(1-\text { cow DMD/100) }+ \text { calf DMI } \\
& \quad \times(1-\text { calf DMD/100) }) \times \text { grazing days }]
\end{aligned}
$$

where DMI = average daily total dry matter intake, and DMD = digestibility $(\%)$ of the dry matter consumed. Total plant residue inputs were converted to $\mathrm{C}$ inputs $\left(\mathrm{kg} \mathrm{C} \mathrm{ha}{ }^{-1}\right.$ $\mathrm{yr}^{-1}$ ) using a factor of 0.45 . Annual manure inputs were converted to $\mathrm{C}$ using a factor of 0.50 to reflect their higher levels of stable forms of $\mathrm{C}$ (Paustian et al. 1992). Plant residue and manure $\mathrm{C}$ inputs $\left(\mathrm{kg} \mathrm{C} \mathrm{ha}^{-1} \mathrm{yr}^{-1}\right)$ above baseline inputs were converted to a rate of SOC accumulation $\left(\mathrm{kg} \mathrm{C} \mathrm{ha}{ }^{-1}\right.$ $\mathrm{yr}^{-1}$ ) by multiplying $\mathrm{C}$ inputs by a coefficient for each region (Table 1) based on estimates made by Campbell et al. (2002) for the Prairie soils in the study. 
As rates of $\mathrm{C}$ accrual typically diminish with time following a beneficial change in management or environment, annual soil $\mathrm{C}$ sequestration rates were reduced by $50 \%$ after each decade (i.e., at 10 and $20 \mathrm{yr}$ ), unless estimated rates of C gain were very low initially $\left(<10 \mathrm{~kg} \mathrm{C} \mathrm{ha}^{-1} \mathrm{yr}^{-1}\right)$. Globally, Conant et al. (2001), found net increases in soil C persisted for at least $40 \mathrm{yr}$ following an improvement in grassland management. IPCC good practice guidelines (Nabuurs et al. 2004) assume net changes in above- and belowground biomass stocks will occur primarily within the first $20 \mathrm{yr}$ following a change in grassland management. Effects of soil texture on $\mathrm{C}$ accumulation were not examined in our modelling exercises and soils were assumed to be medium textured. Finer-textured soils, however, tend to have slower rates of organic matter decomposition due to the formation of clay-organic matter complexes, which resist decomposition (Christensen 1996). More accurate estimates of $\mathrm{C}$ sequestration through improved grazing by region could be obtained by including a weighting factor for the fraction of soil textural class in the coefficients of input to soil $\mathrm{C}$ (Smith et al. 2001). From a hydrological perspective, maintenance of litter carryover through management of grazing intensities (Naeth et al. 1991) may be equally as important as soil textural influences on soil water-holding capacity.

Estimates of the potential hectarage of tame pasture or rangeland within each region to which each management practice could be applied were based on information from local experts concerning the current level of adoption of a grazing management practice. The lack of spatially referenced data on current land use practices on prairie grazingland constitutes a continuing source of uncertainty for these model predictions. The accuracy of estimates of potential regional SOC gains is also reduced by the reliance on the two sites of Melfort and Swift Current as representative of grassland systems within these ecoregions. GrassGro has been shown to accurately predict ANPP and livestock liveweight gain (Cohen et al. 2003). Further testing and calibration with both forage and livestock performance data from experimental sites representing grassland systems at a finer scale within these regions is necessary, however, to reduce the uncertainty associated with these estimates.

\section{RESULTS AND DISCUSSION}

\section{A Note on Exclosures}

The complete exclusion of cattle from native range sites has been suggested as an effective way to increase soil C. We investigated this possibility using the ungrazed pasture option in GrassGro. The annual C inputs at Melfort and Swift Current for moderately grazed and heavily grazed native range over two different season lengths, with or without use of complementary grazing, compared with ungrazed range are presented in Table 4 . The results indicate that at both sites net primary productivity is lower in the absence of grazing. Native rangeland plants have co-evolved with rangeland animals, and a growing body of literature supports the contention that under light grazing pressure (and fire) climax vegetation communities are maintained and the productivity of the native range is maximized. The produc- 


\begin{tabular}{|c|c|c|c|c|c|c|}
\hline \multirow[b]{2}{*}{ Site } & \multicolumn{3}{|c|}{ Grazed } & \multicolumn{3}{|c|}{ Ungrazed } \\
\hline & $\mathrm{CWG}^{\mathbf{y}}$ & CWG/Alfalfa & Native & CWG & CWG/Alfalfa & Native \\
\hline Melfort & 1.5 & 1.5 & 1.7 & 1.2 & 1.2 & 1.4 \\
\hline Swift Current & 2.2 & 2.2 & 2.4 & 1.8 & 1.8 & 2.0 \\
\hline
\end{tabular}

${ }^{\mathbf{z}}$ Estimated on the basis of Sims and Singh (1978) and Parton et al. (1987).

${ }^{\text {yCrested wheatgrass. }}$

tivity of these ecosystems may rely on the stimulation of $\mathrm{C}$ and $\mathrm{N}$ cycling by enhanced incorporation and decomposition of litter by grazing (Schuman et al. 1999; Naeth et al. 1991). Dormaar and Smoliak (1985) found that even after $55 \mathrm{yr}$ of revegetation, abandoned farmland in southern Alberta had still not reached the soil organic $\mathrm{C}$ levels of adjacent native rangeland. Weinhold et al. (2001) similarly reported SOC to be lower after $84 \mathrm{yr}$ of maintaining a native vegetation pasture under exclosure, compared with moderate $\left(2.6\right.$ ha steer $\left.^{-1}\right)$ or heavy $\left(0.9\right.$ ha steer $\left.^{-1}\right)$ grazing regimes. Biondini and Manske (1996) found that in areas that had not been grazed for $30 \mathrm{yr}$ on the native range of North Dakota, less productive cool season, $\mathrm{C}_{3}$ grasses were more prevalent than warm season, $\mathrm{C}_{4}$ grasses. Using $\delta^{13} \mathrm{C}$ techniques, Landi et al. (2003) demonstrated that in the drier, warmer regions of Saskatchewan $\mathrm{C}_{4}$ grasses have contributed substantially to organic matter accumulation. Overall, we conclude that the exclusion of cattle from native range sites is unlikely to be an effective strategy to promote SOC gain.

\section{Potential C Sequestration on Native Rangelands and Tame Pastures}

Averaged over the $30 \mathrm{yr}$, the model predicted annual rates of $\mathrm{C}$ gain per hectare for improved management (excluding $\mathrm{N}$ fertilization) ranged from 2 to $26 \mathrm{~kg} \mathrm{C} \mathrm{ha}^{-1} \mathrm{yr}^{-1}$ for native rangelands and from 62 to $93 \mathrm{~kg} \mathrm{C} \mathrm{ha}^{-1} \mathrm{yr}^{-1}$ for tame pastures (Table 5). Smith et al. (2001), similarly, found projected gains in SOC were very low $\left(<50 \mathrm{~kg} \mathrm{C} \mathrm{ha}^{-1} \mathrm{yr}^{-1}\right)$ following conversion of continuous cropping to no-till for the moisture-deficient Brown and Dark Chernozem soil zones compared with much higher gains of 150 to $200 \mathrm{~kg} \mathrm{C}$ $\mathrm{ha}^{-1} \mathrm{yr}^{-1}$ for cooler dry prairie locations. The gains associated with improved grazing management equal or exceed estimated SOC gains in the arid and semi-arid Chernozems of western Canada from a reduction in summerfallow $(30 \mathrm{~kg}$ $\mathrm{C} \mathrm{ha}^{-1} \mathrm{yr}^{-1}$ ) or increased fertilizer use efficiency (40 kg C $\mathrm{ha}^{-1} \mathrm{yr}^{-1}$ ) (Smith et al. 2001). Across the landbase of Canadian Prairie grassland modelled and assumed to be unimproved (11.5 Mha, or 75\% of 15.3 Mha of grassland), the total annual $\mathrm{C}$ gains are between 0.178 and 0.286 MMT $\mathrm{C} \mathrm{yr}^{-1}$ when the $\mathrm{N}$ fertilizer (FERT) treatment is excluded from the calculations (Table 5). Over the projected 30-yr timeframe an upper limit of 8.58 MMTC gain is suggested from best management of tame pasture and grazingland combined. With inclusion of the FERT treatment, this rises

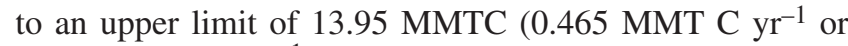
1.63 $\mathrm{MMT} \mathrm{CO}_{2} \mathrm{yr}^{-1}$ ). This is slightly less than the approximately $1.70 \mathrm{MMT} \mathrm{yr}^{-1}$ net $\mathrm{CO}_{2}$ considered emitted from soils due to agricultural activity in Canada (AAFC 1999). Schuman et al. (2001) estimated slightly higher potential C sequestration rates of 50 to $150 \mathrm{~kg} \mathrm{C} \mathrm{ha}^{-1} \mathrm{yr}^{-1}$ for US rangelands that were previously poorly managed. Grazingland occupies more than twice the area of cropland in the United States. The substantially greater estimates of total soil C accrual per year of 5.4 to 16.0 MMTC (Schuman et al. $2001)$, are also due to the much greater ( 10-fold ) land-base of 107 Mha of private US rangeland to which these C sequestration rates may be applied.

Bruce et al. (1999) projected potential gains of 221 MMTC over the next two decades through improved management (fertilization) of the 4.3 Mha of "intensive" grasslands in Canada. The rate of $\mathrm{C}$ gain of $200 \mathrm{~kg} \mathrm{C} \mathrm{ha}^{-1} \mathrm{yr}^{-1}$ through fertilization, however, was assumed constant over the projected 20-yr timeframe, and no discount for the $\mathrm{C}$ costs of $\mathrm{N}$ fertilizer production and transport was included in this estimate. In the Aspen Parkland/Boreal Transition region, application of $\mathrm{N}$ fertilizer at $100 \mathrm{~kg} \mathrm{~N} \mathrm{ha}^{-1}$ was estimated to increase $\mathrm{C}$ sequestration rates to $222 \mathrm{~kg} \mathrm{C} \mathrm{ha}^{-1} \mathrm{yr}^{-1}$ when averaged over the projected $30 \mathrm{yr}$ (Table 5), the highest rate of $\mathrm{C}$ accrual of all practices examined. Similarly, Conant et al. (2001), reported a global average $\mathrm{C}$ gain of about $290 \mathrm{~kg} \mathrm{C} \mathrm{ha}^{-1} \mathrm{yr}^{-1}$ following inorganic fertilizer application to grassland soils. The high production and transportation energy (C) costs associated with $\mathrm{N}$ fertilizer use may, however, largely negate these $\mathrm{C}$ gains (Schlesinger 2000; Conant et al. 2001). Also, the use of ammonium nitrate or urea as $\mathrm{N}$ fertilizers promotes acidification following nitrification of ammonium. If calcium carbonate is used to neutralize this acidity, $0.43 \mathrm{~kg} \mathrm{C} \mathrm{kg}^{-1} \mathrm{~N}$ is converted to $\mathrm{CO}_{2}$ and lost to the atmosphere (Schnabel et al. 2001). Finally, as rates of $\mathrm{C}$ gain decrease with this practice over time from $275 \mathrm{~kg} \mathrm{C} \mathrm{ha}^{-1} \mathrm{yr}^{-1}\left(963 \mathrm{~kg} \mathrm{CO}_{2}\right)$ in the first decade to $68.9 \mathrm{~kg} \mathrm{C} \mathrm{ha}^{-1} \mathrm{yr}^{-1}\left(240 \mathrm{~kg} \mathrm{CO}_{2}\right)$ by the third decade emissions of $\mathrm{N}_{2} \mathrm{O}$ (310 times more effective at warming the atmosphere than $\mathrm{CO}_{2}$ ) equivalent to $387.5 \mathrm{~kg}$ $\mathrm{CO}_{2} \mathrm{yr}^{-1}$ [1.25\% of $\mathrm{N}$ applied (AAFC 1999); data not shown] following fertilizer application, will gradually negate any remaining $\mathrm{C}$ gains associated with fertilization. In unfertilized grassland soils, ammonium and nitrate levels are usually very low, and tame pasture systems with legumes can be effectively managed without $\mathrm{N}$ fertilizer use (Schuman et al. 1999). At high levels of $\mathrm{N}$ inputs $\mathrm{C}_{4}$ grasses are difficult to maintain in the sward (Wedin and Tilman 1996; Schnabel et al. 2001). Wedin and Tilman (1996) found plot $\mathrm{C}_{4}$ biomass to be the best single predictor of soil $\mathrm{C}$ storage in Minnesota grasslands with shifts to $\mathrm{C}_{3}$ grasses occurring at greater than $50 \mathrm{~kg} \mathrm{~N} \mathrm{ha}^{-1} \mathrm{yr}^{-1}$ fertilizer $\mathrm{N}$. In an assessment of data collected from 62 long-term studies of SOC sequestration under cultivated agricultural land in Canada, VandenBygaart et al. (2003) found a much stronger 


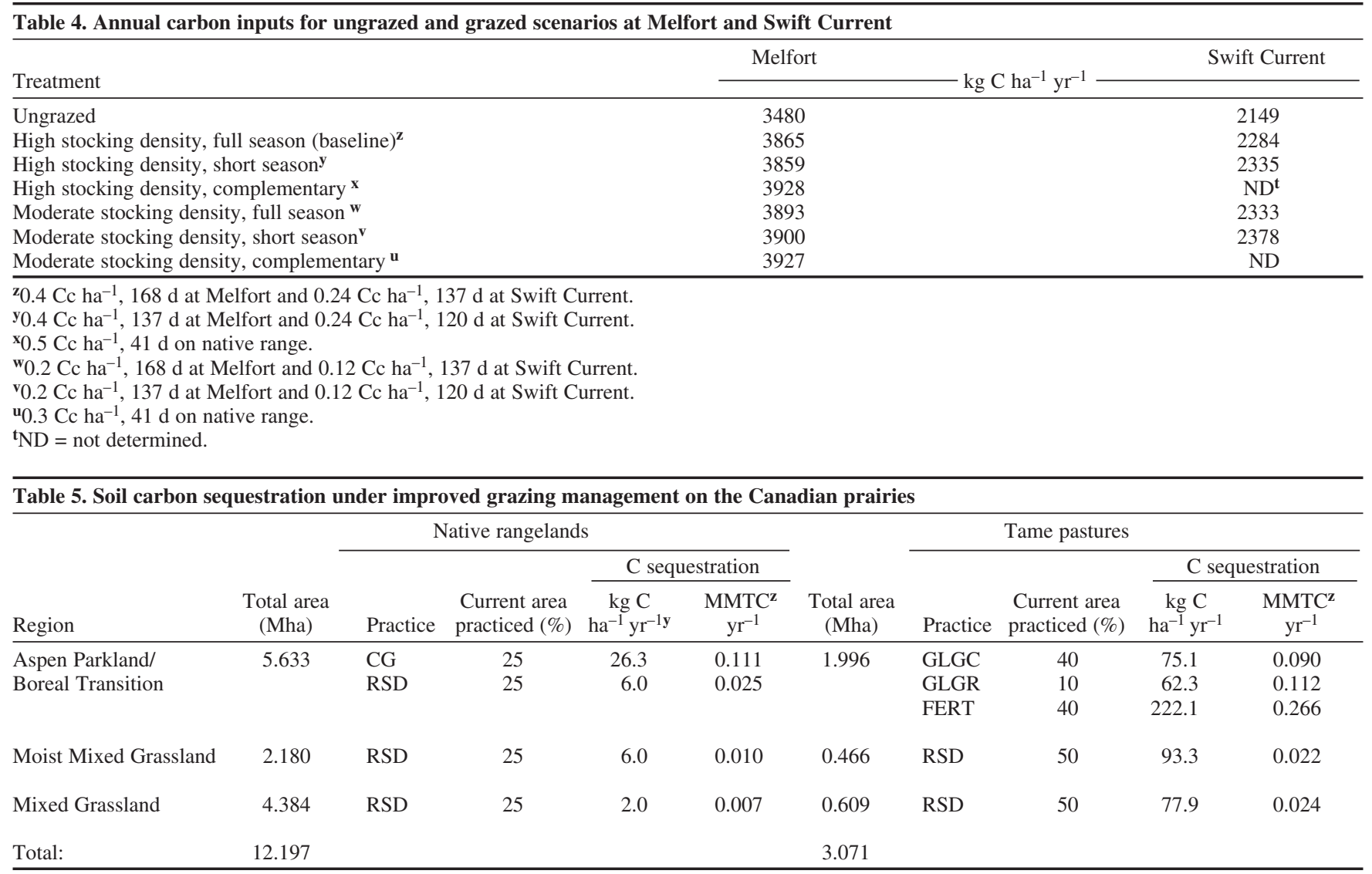

${ }^{\mathbf{z}}$ MMTC $=$ million metric tons of carbon.

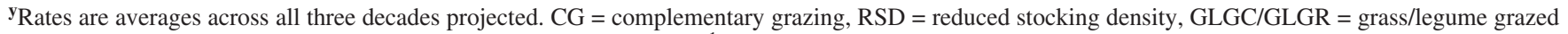
continuously/rotationally, FERT $=\mathrm{N}$ fertilizer applied at $100 \mathrm{~kg} \mathrm{~N} \mathrm{ha}^{-1}$.

relationship $\left(r^{2}=0.76\right)$ between $\mathrm{N}$ fertilizer use and SOC gains when application rates were less than $50 \mathrm{~kg} \mathrm{~N}$ ha $^{-1}$ $\mathrm{yr}^{-1}$, than for all application rates $\left(r^{2}=0.18\right)$. The results suggest an improved efficiency of plant $\mathrm{N}$ use, and associated SOC storage, at lower $\mathrm{N}$ input rates.

Introducing and maintaining a legume component in grazed ecosystems may provide $\mathrm{N}$ to the system closer to an optimum range for net $\mathrm{C}$ gain, and improve the energy efficiency, of these agroecosystems (Janzen et al. 1998b). Legumes, by increasing forage quality, also provide the additional benefit of enhancing livestock productivity. Conant et al. (2002) assessed the effect of improved management practices, including sowing of legumes or fertilization, on $\mathrm{C}$ sequestration under pastures in the southeastern United States. Data on C sequestration rates from a literature review were reclassified based on ratios of precipitation to potential evapotranspiration (PPT/PET) appropriate to the states in the region. Regardless of moisture regime, soil C increased more when legumes were sown $(0.298$ to 0.382 $\left.\mathrm{Mg} \mathrm{C} \mathrm{ha}{ }^{-1} \mathrm{yr}^{-1}\right)$ than when fertilizer was added (0.137 to $0.201 \mathrm{MgC} \mathrm{ha}^{-1} \mathrm{yr}^{-1}$ ) (Conant et al. 2002). The authors note, however, that emission costs (in the order of $0.82 \mathrm{~kg}$ $\left.\mathrm{CO}_{2}-\mathrm{C}\right)$ per $\mathrm{kg} \mathrm{N}$ manufactured significantly reduce the net benefits of $\mathrm{N}$ fertilizer use. A survey of state extension agents provided information on the current state of pasture management. At adoption rates of 10 and 50\%, improved management was estimated to provide gains of between 1 and 4 MMTC $\mathrm{yr}^{-1}$, respectively. In the current study, the practice of sowing various grass/legume mixtures into tame pastures of moist prairie regions, and grazing either continuously (GLGC) or rotationally (GLGR)(Table 2), was estimated to increase soil C by 0.075 to $0.062 \mathrm{MgC} \mathrm{ha}^{-1} \mathrm{yr}^{-1}$, respectively. The somewhat lower $\mathrm{C}$ returns to soil under GLGR reflect an improved efficiency of sward use by livestock associated with rotational grazing systems. Such small differences in SOC gains between grazing strategies are unlikely to be significant, as found by Manley et al. (1995).

At matched stocking density to that of the baseline scenario $\left(0.4 \mathrm{Cc} \mathrm{ha}^{-1}\right), \mathrm{CG}$ showed greater benefits with respect to $\mathrm{C}$ gains (26 kg C ha $\mathrm{yr}^{-1}$ ) on native rangelands of the moist prairie region, when compared to RSD (6 kg C ha ${ }^{-1}$ $\left.\mathrm{yr}^{-1}\right)$ (Table 5). Even at higher SD $\left(0.5 \mathrm{Cc} \mathrm{ha}^{-1}\right)$, annual C returns are greater than the baseline scenario. While this management option was only run for the Melfort site (moist prairie), this system would be applicable to some of the mixed grassland area within the dry prairie region, further adding to the large land base to which these rates of $\mathrm{C}$ accrual could apply. Increased adoption of CG management systems thus appears to offer the greatest potential for SOC gains on Prairie region grazed grasslands. 


\begin{tabular}{|c|c|c|c|c|c|}
\hline Practice & $\begin{array}{l}\text { Changes in } \mathrm{COP}^{\mathrm{z}} \\
\left(\$ \mathrm{yr}^{-1}\right)\end{array}$ & $\begin{array}{l}\text { Calves sold change } \\
\left(\# \mathrm{yr}^{-1}\right)\end{array}$ & $\begin{array}{c}\text { Weaning weight } \\
\text { change }(\mathrm{kg} \text { animal }\end{array}$ & $\begin{array}{l}\text { Profit/loss } \\
\left(\$ \text { animal }^{-1}\right)\end{array}$ & $\begin{array}{l}\text { Change in end of } \\
\text { grazing season net returns }(\$)\end{array}$ \\
\hline $\mathrm{CG}$ & $+1,000^{\mathbf{y}}$ & +4 & $\begin{array}{l}\text { Native rangelands } \\
\qquad+25\end{array}$ & +51.11 & $+4,485$ \\
\hline RSD & $-4805.50^{x}$ & -31 & +2 & +4.10 & $-10,380$ \\
\hline RSD & $-3464.50^{x}$ & -14 & +2 & +4.10 & $-2,598$ \\
\hline & & & Tame pastures & & \\
\hline GLGC & $+3,500^{y}$ & +4 & -23 & -47 & -9258 \\
\hline GLGR & $+3,000^{w}$ & 0 & -5 & -10 & $-2587^{v}$ \\
\hline RSD & $-1,3642^{\mathbf{x}}$ & -6 & +27 & +55 & +334 \\
\hline FERT & $+14,348^{\mathbf{u}}$ & +5 & +36 & +73 & $+7,336$ \\
\hline
\end{tabular}

${ }^{\mathrm{z}} \mathrm{COP}=$ cost of production for a 300-ha ranch.

$\mathbf{y}_{\text {Annual seed costs. }}$

${ }^{\mathbf{x}}$ Represents reductions in stored feed costs over the winter.

${ }^{\text {w}}$ Annual fence maintenance costs.

vWith initial fencing costs of $\$ 15000$ included in calculation.

uAnnual fertilizer costs (at $\$ 300$ per tonne urea)

$\mathrm{CG}=$ complementary grazing; RSD = reduced stocking density, GLGC/GLGR = grass /legume grazed continuously/rotationally, FERT = N fertilizer applied at $100 \mathrm{~kg} \mathrm{~N} \mathrm{ha}^{-1}$.

\section{Livestock Productivity and Profitability of Grazing Management Options}

A 300-ha ranch at Melfort stocked at $0.4 \mathrm{Cc} \mathrm{ha}^{-1}$ and using the native range for 168 days a year (baseline scenario) will operate with gross margins of \$20 972 per year based on GrassGro results. On tame pastures, the baseline scenario of a CWG monoculture, grazed continuously at a stocking rate of $0.5 \mathrm{Cc} \mathrm{ha}^{-1}$, will generate gross margins of $\$ 27428$. Of the various improved management options assessed for native rangeland, the $\mathrm{CG}$ system appears to be most profitable (Table 6). At matched stocking densities $\left(0.4 \mathrm{Cc} \mathrm{ha}^{-1}\right)$ to the baseline system, the number of animals weaned per ranch is slightly higher (by four animals) and weaning weights are higher so that ranchers can expect an increase in gross income from sales of $\$ 4485$ based on an average for steers or heifers of $\$ 51.11 /$ animal. Under the CG system, there would be some investment (we estimated \$1000), varying greatly depending on the circumstances of each individual ranch, necessary to establish pastures of CWG and Russian wild rye on ranches that do not already have these crops. If properly managed, however, this should be a one-time expense. The CG system can likely sustain even higher stocking rates in moist prairie regions. The GrassGro model suggested net returns further increased under CG to $\$ 9779$ (data not shown) when SD attains $0.5 \mathrm{Cc} \mathrm{ha}^{-1}$. Gains in SOC of $26.3 \mathrm{~kg} \mathrm{C} \mathrm{ha}^{-1}$ (or $92 \mathrm{~kg} \mathrm{CO}_{2}$, Table 5) would be offset by higher $\mathrm{CH}_{4}$ and $\mathrm{N}_{2} \mathrm{O}$ (equivalent to $252 \mathrm{~kg} \mathrm{CO}$ $\mathrm{ha}^{-1} \mathrm{yr}^{-1}$, data not shown) associated with the higher SD, however. Cohen et al. (1995) found calf liveweight gain peaked in mid August if CWG alone was continuously grazed, while moving the cows and calves to Russian wild ryegrass pasture in late summer/early fall maintained weight gain through to weaning. Gillen and Berg (2001), however, found that although per-hectare livestock production was improved by $64 \%$ under a complementary grazing system that combined native pasture and Old World bluestems (Bothriochloa spp.), the relative costs of production over 5 $\mathrm{yr}$ favoured the continuous native pasture system.

The marginal gains in SOC through reduced SD on native rangelands were offset by greatly reduced profits for ranch- ers (Table 6). At the Melfort site, reducing the stocking density from 0.4 to $0.2 \mathrm{Cc} \mathrm{ha}^{-1}$ resulted in reductions in gross income from sales of steers and heifers of $\$ 10,380$. Using similar assumptions, the owner of a 300-ha model ranch in the dry prairie saved $\$ 3464.50 \mathrm{yr}^{-1}$ in stored feed costs by reducing $\mathrm{SD}$ on the native range portion of the ranch. Although weaning weights of animals are higher, fewer animals sold results in lower returns (-\$2598) at the end of the grazing season, which counters the lower winter feeding costs. In contrast, on tame pastures of the dry prairie regions, no penalty with respect to net returns was incurred by reducing SD slightly (Table 6), while gains in SOC were relatively large ( 78 to $93 \mathrm{~kg} \mathrm{C} \mathrm{ha}^{-1} \mathrm{yr}^{-1}$ ). This is due to the higher weaning weights of the calves, which more than compensate for the slight reductions in numbers of calves sold. The reduction in winter feeding costs will also increase the profits of this system relative to the baseline, higher stocking density scenario. While there appear to be financial benefits and soil $\mathrm{C}$ gains achievable through RSD, particularly on tame pastures, perceived loss of income may be a barrier to widespread adoption of this practice.

As additions of $\mathrm{N}$ fertilizer increase ANPP, larger numbers of calves are weaned with higher weaning weights. While gross income gains were greatest $(+\$ 7336)$ under the FERT option, returns remained negative, however, as a result of the relatively high cost of fertilizer inputs (Table 6). While profitability will be enhanced by increasing stocking density, reducing $\mathrm{N}$ application rates to closer to $50 \mathrm{~kg} \mathrm{~N} \mathrm{ha}^{-1} \mathrm{yr}^{-1}$, as discussed above, will also provide for SOC gains.

Costs associated with system establishment and maintenance impacted negatively on profitability of renovating tame pastures with introduced grass and legume species. Seed cost for the reseeded continuously grazed CWG/alfal$\mathrm{fa}$ (GLGC) was estimated to be $\$ 3500 \mathrm{yr}^{-1}$. This is based on a ranch with 210 ha of grass/legume pasture, seeded at a rate of $10 \mathrm{~kg}$ alfalfa ha ${ }^{-1}$, valued at $\$ 8.52 \mathrm{~kg}^{-1}$. Annual maintenance costs for the rotational grazing system (GLGR) were estimated to be about $\$ 3000$ ( $\$ 1000$ for fuel, $\$ 1850$ for fence maintenance, and $\$ 150$ for electricity), extrapolated from documented costs for a system in Nova Scotia 
(Thomas et al. 1995). GrassGro results suggest that, because of greater productivity of the GLGR system, herd size could be increased to 200 (i.e., $0.67 \mathrm{Cc} \mathrm{ha}^{-1}$ ) over time, with a gain in farm profits of $\$ 9452$ (data not shown). However, any SOC gains (of $75.1 \mathrm{~kg} \mathrm{C} \mathrm{ha}^{-1} \mathrm{yr}^{-1}$ or $263 \mathrm{~kg} \mathrm{CO}_{2} \mathrm{ha}^{-1} \mathrm{yr}^{-1}$, Table 5) would be negated by the higher methane and nitrous oxide emissions (equivalent to $429 \mathrm{~kg} \mathrm{CO}_{2} \mathrm{ha}^{-1} \mathrm{yr}^{-1}$, data not shown) associated with the larger SD. More research is needed to determine the most cost-effective method of seeding alfalfa and other legumes into improved tame pastures, including no-till methods such as frost seeding, feeding of the seed to cattle, or seed drilling with a notill drill. Indications of reductions in methane emissions from cattle on grass/legume pastures compared to cattle on pure grass stands (McCaughey et al. 1997) or when finished in feedlots (Cohen et al. 2004), and evidence of lower $\mathrm{N}_{2} \mathrm{O}$ emissions from legume stands than from $\mathrm{N}$ fertilized systems (Wagner-Riddle et al. 1997), provide additional justification for such efforts.

\section{CONCLUSIONS}

Among the grazing management options assessed here, complementary grazing appears to offer the combined benefit of SOC gains, while providing enhanced net returns to the producer. Much more needs to be done to characterize the constraints to possible adoption of any improved grazing practice at the farm level, which will necessarily include developing a functional classification of current land use practices on grazingland in Canada. An equally important hurdle remains the wide variability to date, in grazing study design (lack of standardization of soil sampling, $\mathrm{C}$ measurement techniques, and data reporting methods, etc.), which accounts for much of the inconsistency of reported SOC response to grazing management regime (Milchunas and Lauenroth 1993; Schuman et al. 2001; Conant et al. 2001; Henderson et al. 2004). As such land use data bases develop, and the number of research studies on Canadian grazinglands targeted to assess soil $\mathrm{C}$ dynamics increases, confidence limits can be included with estimates of SOC gain under grazing. Notwithstanding these limitations, the present study provides a first objective assessment of the potential changes in soil $\mathrm{C}$ storage, and the economic feasibility, of a range of potential improved practices for grazinglands of the Canadian Prairies.

\section{ACKNOWLEDGEMENTS}

We are grateful to Mike Main and Julia Cooper, Nova Scotia Agricultural College, for their assistance in the preparation of this manuscript. Thanks also are due to Drs. Martin Entz, (University of Manitoba), and Marcia Monreal (AAFC Brandon) for sharing their valuable experience with us. Funding for the initial research was provided through the Agriculture and Agri-Food Climate Change Table, Environment Bureau.

Agriculture and Agri-Food Canada. 1995. Ecological Stratification Working Group. A National Ecological Framework for Canada. Agriculture and Agri-Food Canada, Research Branch, Ottawa, ON. 125 pp.
Agriculture and Agri-Food Canada. 1999. Agriculture and AgriFood Canada Climate Change Foundation Paper. Agriculture and Agri-Food Canada Climate Change Table, Ottawa, ON. 74 pp.

Bari, F., Wood, M. and Murray, L. 1993. Livestock grazing impacts on infiltration rates in a temperate range of Pakistan. J. Range Manage. 46: 367-372.

Barker, J. R., Baumgardner, G. A., Turner, D. P. and Lee, J. J. 1996. Carbon dynamics of the Conservation and Wetland Reserve Programs. J. Soil Water Cons. 51: 340-346.

Biondini, M. E. and Manske, L. L. 1996. Grazing frequency and ecosystem processes in a northern mixed prairie. Ecol. Appl. 6: 239-256.

Bruce, J. P., Frome, M., Haites, E., Janzen, H., Lal, R. and Paustian, K. 1999. Carbon sequestration in soils. J. Soil Water Cons. 54: 382-389.

Burke, I. C., Lauenroth, W. K., Vinton, M. A., Hook, P. B., Kelly, R. H., Epstein, H. E., Aguiar, M. R., Robles, M. D., Aguilera, M. O., Murphy, K. L. and Gill, R. A. 1998. Plant-soil interactions in temperate grasslands. Biogeochemistry 42: 121-143.

Campbell, C. A., McConkey, B. G., Gameda, S., Izaurralde, R. C., Liang, B. C., Zentner, R. P. and Sabourin, D. 2002. Efficiencies of conversion of residue $\mathrm{C}$ to soil C. Pages 305-313 in J. M. Kimble, J. Lal, and R. F. Follett, eds. Agricultural practices and policies for carbon sequestration in soil. CRC Press/Lewis Publishers, New York, NY.

Campbell, C. A., Selles, F., Lafond, G. P. and Zentner, R. P. 2001. Adopting zero tillage management: Impact on soil $\mathrm{C}$ and $\mathrm{N}$ under long-term crop rotations in a thin Black Chernozem. Can. J. Soil Sci. 81: 139-148.

Campbell, C. A., Zentner, R. P., Liang, B. C., Roloff, G., Gregorich, E. C. and Blomert, B. 2000. Organic C accumulation in soil over 30 years in semiarid southwestern SaskatchewanEffect of crop rotations and fertilizers. Can. J. Soil Sci. 80: 179-192.

Chanasyk, D. S. and Naeth, M. A. 1995. Grazing impacts on bulk density and soil strength in the foothills fescue grasslands of Alberta, Canada. Can. J. Soil Sci. 75: 551-559.

Christensen, B. T. 1996. Carbon in primary and secondary organomineral complexes. Pages 97-165 in M. R. Carter and B. A. Stewart, eds. Structure and organic matter storage in agricultural soils. CRC Press/Lewis Publishers, New York, NY.

Cohen, R. D. H., Donnelly, J. R., Moore, A. D., Leech, F., Bruynooghe, J. D. and Lardner, H. A. 1995. GrassGro - a computer decision support system for pasture and livestock management. Proc. West. Sec. Am. Soc. Anim. Sci. 46: 376-379.

Cohen, R. D. H., Stevens, J. P., Moore, A. D. and Donnelly, J. R. 2003. Validating and using the GrassGro decision support tool for a mixed grass/alfalfa pasture in western Canada. Can. J. Anim. Sci. 83: 171-182.

Cohen, R. D. H., Stevens, J. P., Moore, A. D., Donnelly, J. R. and Freer, M. 2004. Predicting methane emissions and metabolizable energy intakes of steers grazing a grass/alfalfa pasture and finished in a feedlot or at pasture using the GrassGro decision support tool. Can. J. Anim. Sci. 84: 125-132.

Conant, R. T., Paustian, K. and Elliott, E. 2001. Grassland management and conversion into grassland: Effects on soil carbon. Ecol. Appl. 11: 343-355.

Conant, R. T., Paustian, K. and Elliott, E. 2002. Pastureland use in the Southeastern U.S.: Implications for carbon sequestration. Pages 423-432 in J. L. Kimble, R. Lal, and R. F. Follett, eds. Agricultural practices and policies for carbon sequestration in soil. CRC Press/Lewis Publishers, New York, NY.

Dormaar, J. F. and Smoliak, S. 1985. Recovery of vegetative cover and soil organic matter during revegetation of abandoned farmland in a semi-arid climate. J. Range Manage. 38: 487-491. 
Follett, R. F., Kimble, J. M. and Lal, R. 2001. The potential of U.S. grazing lands to sequester soil carbon. Pages 401-430 in R. F. Follett, J. M. Kimble, and R. Lal, eds. The potential of U.S. grazing lands to sequester carbon and mitigate the greenhouse effect. CRC Press/Lewis Publishers, New York, NY.

Franzlubbers, A. J., Stuedemann, J. A., Schomberg, H. H. and Wilkinson, S. R. 2000. Soil organic $\mathrm{C}$ and $\mathrm{N}$ pools under longterm pasture management in the Southern Piedmont USA. Soil Biol. Biochem. 32: 469-478.

Gillen, R. L. and Berg, W. A. 2001. Complementary grazing of native pasture and Old World bluestem. J. Range Manage. 54: 348-355.

Henderson, D. C., Ellert, B. H. and Naeth, M. A. 2004. Grazing and soil carbon along a gradient of Alberta rangelands. J. Range Manage. 57: 402-410.

Intergovernmental Panel on Climate Change. 2001. Climate change. Mitigation. A Report of Working Group III of the Intergovernmental Panel on Climate Change. Geneva, Switzerland.

Janzen, H. H., Campbell, C. A., Izaurralde, R. C., Ellert, B. H., Juma, N., McGill, W. B. and Zentner, R. P. 1998a. Management effects on soil C storage on the Canadian prairies. Soil Tillage Res. 47: $181-195$.

Janzen, H. H., Campbell, C. A., Gregorich, E. G. and Ellert B. H. 1998b. Soil carbon dynamics in Canadian agroecosystems. Pages 57-80 in R. Lal, J. M., Kimble, R. F. Follett, and B. A. Stewart, eds. Soil processes and the carbon cycle. CRC Press, New York, NY.

Landi, A., Anderson, D. W. and Mermut, A. R. 2003. Organic carbon storage and stable isotope composition of soils along a grassland to forest environmental gradient in Saskatchewan. Can. J. Soil Sci. 83: 405-414.

Manley, J. T., Schuman, G. E., Reeder, J. D. and Hart, R. H. 1995. Rangeland soil carbon and nitrogen responses to grazing. J. Soil Water Cons. 50: 294-298.

McCaughey, W. P., Wittenberg, K. and Corrigan, D. 1997. Methane production by lactating beef cows on pasture. Can J. Anim. Sci. 77: 519-524.

Milchunas, D. G. and Lauenroth, W. K. 1993. Quantitative effects of grazing on vegetation and soils over a global range of environments. Ecol. Monogr. 63: 327-366.

Naburrs, G. J., Ravindrath, N. H., Paustian, K. P., Fribauer, A., Hohenstein, W. and Makundi, W. 2004. LUCF-sector good practice guidance. in IPCC good practice guidance for LULUCF. Institute for Global Environmental Strategies, Hayama, Japan. [Online] Available: http://www.ipcc-nggip.iges.or.jp/lulucf.html [2004 Dec. 02].

Naeth, M. A., Bailey, A. W., Pluth, D. J., Chanasyk, D. S. and Hardin, R. T. 1991. Grazing impacts on litter and soil organic matter in mixed prairie and fescue grassland ecosystems of Alberta. J. Range Manage. 44: 7-12.

Parton, W. J., Schimel, D. S., Cole, C. V. and Ojima, D. S. 1987. Analysis of factors controlling soil organic matter levels in great plains grasslands. Soil Sci. Soc. Am. J. 51: 1173-1179.

Paustian, K., Parton, W. J. and Paersson, J. 1992. Modelling soil organic matter in organic-amended and nitrogen-fertilized long-term plots. Soil Sci. Soc. Am. J. 56: 476-488.

Prairie Farm Rehabilitation Administration. 2000. Prairie agricultural landscapes: A land resource review. Prairie Farm Rehabilitation Administration, Agriculture and Agri-Food Canada, Regina, SK. 179 pp.

Reeder, J. D., Franks, C. D. and Milchunas, D. G. 2001. Root biomass and microbial processes. Pages 139-166 in R. F. Follett, J. M. Kimble, and R. Lal, eds. The potential of U.S. grazing lands to sequester carbon and mitigate the greenhouse effect. CRC Press/Lewis Publishers, New York, NY.
Sala, O. E., Parton, W. J., Joyce, L. A. and Lauenroth, W. K. 1988. Primary production of the central grassland region of the United States. Ecology 69: 40-45.

Schimel, D. S. 1995. Terrestrial ecosystems and the carbon cycle. Global Change Biol. 1: 77-91.

Schlesinger, W. H. 2000. Carbon sequestration in soils: some cautions amidst optimism. Agric. Ecosyst. Environ. 82: 121-127.

Schnabel, R. R.., Franzluebbers, A. J., Sout, W. L., Sanderson, M. A. and Stuedemann, J. A. 2001. The effects of pasture management practices. Pages 291-322 in R. F. Follett, J. M. Kimble, and R. Lal, eds. The potential of U.S. grazing lands to sequester carbon and mitigate the greenhouse effect. CRC Press/Lewis Publishers, New York, NY.

Schuman, G. E., Herrick, J. E. and Janzen, H. H. 2001. The dynamics of soil carbon in rangelands. Pages 267-290 in R. F. Follett, J. M. Kimble, and R. Lal, eds. The potential of U.S. grazing lands to sequester carbon and mitigate the greenhouse effect. CRC Press/Lewis Publishers, New York, NY.

Schuman, G. E., Reeder, J. D., Manley, J. T., Hart, R. H. and Manley, W. A. 1999. Impact of grazing management on the carbon and nitrogen balance of a mixed-grass rangeland. Ecol. Applic. 9: 65-71.

Sims, P. L. and Singh, J. S. 1978. The structure and function of ten western north american grasslands. III. Net primary production, turnover and efficiencies of energy capture and water use. J. Ecol. 66: $573-597$.

Smith, W. N., Desjardins, R. L. and Grant, B. 2001. Estimated changes in soil carbon associated with agricultural practices in Canada. Can. J. Soil Sci. 81: 221-227.

Smith, W. N., Rochette, P., Monreal, C., Desjardins, R. L., Pattey, E. and Jaques, A. 1997. The rate of carbon change in agricultural soils in Canada at the landscape level. Can. J. Soil Sci. 77: 219-229.

Smith, W. N., Wall, G., Desjardins, R. and Grant, B. 2000. Soil organic carbon. Pages 85-103 in T. McRae, C. A. S. Smith, and L. J. Gregorich, eds. Environmental sustainability of canadian agriculture. Report of the Agri-Environmental Indicator Project. Agriculture and Agri-Food Canada, Ottawa, ON. pp 224.

Statistics Canada. 1996. Census of agriculture. Statistics Canada, Ottawa, ON.

Tarnocai, D. 1998. The amount of organic carbon in various soil orders and ecological provinces in Canada. Pages 81-93 in R. Lal, J. M. Kimble, R. F. Follett, and B. A. Stewart, eds. Soil processes and the carbon cycle. CRC Press, New York, NY

Thomas, B., Marsh, T. and Knight, A. 1995. Characterization of a native pasture sward under intensive grazing management over one grazing season. Nova Scotia Department of Agriculture and Marketing, Plant Industry Branch, Project Reports, Truro, NS.

VandenBygaart, A. J., Gregorich, E. G. and Angers, D. A. 2003. Influence if agricultural management on soil organic carbon: A compendium and assessment of Canadian studies. Can. J. Soil. Sci. 83: 363-380.

Wagner-Riddle, C., Thurtell, G. W., Kidd, G. K., Beauchamp, E. G. and Seetman, R. 1997. Estimates of nitrous oxide emissions from agricultural fields over 28 months. Can. J. Soil Sci. 77: 135-144.

Wedin, D. A. and Tilman, D. 1996. Influence of nitrogen loading and species composition on the carbon balance of grasslands. Science 274: 1720-1723.

Weinhold, B. J., Hendrickson, J. R. and Karn, J. F. 2001. Pasture management influences on soil properties in the northern Great Plains. J. Soil Water Cons. 56: 27-31. 